\title{
Growth performance of Noble Crayfish Astacus astacus in recirculating aquaculture systems
}

\author{
Uli B. Seemann • Kai Lorkowski • Matthew J. Slater • \\ Friedrich Buchholz • Bela H. Buck
}

Received: 26 May 2014/ Accepted: 14 November 2014

(C) Springer International Publishing Switzerland 2014

\begin{abstract}
There is growing interest in using recirculating aquaculture systems (RAS) to raise noble crayfish Astacus astacus a valuable and once plentiful food species in Europe, now a highly endangered species. The growth and survival of A. astacus was compared in growth trials in RAS and open-pond systems (OPS) over a period of 2 months. Energy and lipid content of available diets and crayfish tissue were also determined. Growth of $A$. astacus during summer was significantly ( $p<0.01$, one sample $t$ test) higher in OPS (SGR 1.23) than in RAS even at the highest feeding ration provided at $5 \% \mathrm{bw} / \mathrm{d}^{-1}$ (RAS HI SGR $0.78 \pm 0.06)$. OPS crayfish also had significantly $(p<0.01$ OPS vs. all RAS treatments; Pairwise Wilcoxon) higher lipid content $(8.51 \%)$ than RAS crayfish (RAS HI $5.73 \%$, RAS MED $6.93 \%$, RAS LOW $5.92 \%$ ). Survival rates in RAS were, however, $100 \%$ compared with previous observations in OPS of approx. $70 \%$. While results showed OPS growth exceeds than that in RAS in the short term, RAS survival rates and annualized growth performance may outweigh this disadvantage, particularly if optimal artificial diets for RAS holding are provided. Feed and crayfish analysis indicated that culturing $A$. astacus in RAS require a diet protein content exceeding $30 \%$ and lipid content of $<13 \%$, indicating that the carp diet supplied was not optimal. RAS culture allows this valuable species to be cultured in controlled, disease-free enclosed systems-resulting in high-value food products as well as high-quality seedlings for restocking purpose.
\end{abstract}

Keywords Astacus astacus $\cdot$ Crayfish feed $\cdot$ Feed ratio $\cdot$ Lipid content $\cdot$ Pond system

U. B. Seemann $(\bowtie) \cdot$ M. J. Slater

Institute for Marine Resources GmbH, Bussestr. 27, 27570 Bremerhaven, Germany

e-mail: uli.seemann@awi.de

U. B. Seemann · K. Lorkowski · M. J. Slater · F. Buchholz · B. H. Buck

Alfred Wegener Institute Helmholtz Center for Polar and Marine Research, 27570 Bremerhaven,

Germany

K. Lorkowski · B. H. Buck

University of Applied Sciences Bremerhaven, 27568 Bremerhaven, Germany 


$\begin{array}{ll}\text { Abbreviations } \\ \mathrm{A}_{\mathrm{FK}} & \text { Surface of filter body }\left[\mathrm{m}^{2} / \mathrm{m}^{3}\right] 600 \mathrm{~m}^{2} / \mathrm{m}^{3} \text { (Spieck et al. 2007) } \\ \mathrm{AN} & \text { Amount of affiliated nitrogen }(80 \% \text {, van Wyk 1999) } \\ \mathrm{E}_{\mathrm{NH} 3} & \text { Ammonia nitrogen amount of excretion }(75 \% \text {, van Wyk 1999) } \\ \mathrm{FI}_{\max } & \text { Max. feed intake per day }[\mathrm{g}] \\ \mathrm{NC} & \text { Amount of nitrogen in the protein }(16 \% \text {; van Wyk 1999) } \\ \mathrm{NR} & \text { Nitrification rate of filter body }\left[\mathrm{gN} / \mathrm{m}^{2} \mathrm{~d}\right] \\ \mathrm{OPS} & \text { Open-pond systems } \\ \text { PC } & \text { Amount of protein in the feed }(25 \%, \text { CYPRININ K2) } \\ \text { RAS } & \text { Recirculating aquaculture systems } \\ \text { RAS HI } & \text { Treatment of } 5 \% \\ \text { RAS LOW } & \text { Treatment of } 3 \% \\ \text { RAS MED } & \text { Treatment of } 4 \% \\ \text { TAN } & \text { Total amount of imported nitrogen }[\mathrm{gN} / \mathrm{d}] \\ \mathrm{V}_{\mathrm{BF}} & \text { Volume of biofilter }\left[\mathrm{m}^{3}\right]\end{array}$

\section{Introduction}

The noble crayfish Astacus astacus is a native species in Europe and was once found in nearly all freshwater systems (Ingle 1997; Westman 2002). It was previously a common food source in Europe (Cukerzis 1988; Skurdal and Taugbøl 2001; Holdich 2002). After the introduction of the American crayfish species, Pacifastacus leniusculus and Orconectes limosus, in the late nineteenth century and concomitant highly infectious crayfish plague (Aphanomyces astaci), vast populations perished and A. astacus numbers in Europe decreased drastically (Edgerton et al. 2002; Westman and Savolainen 2001; Holdich et al. 2009; Holdich 2002). Other factors like water pollution and habitat alteration and destruction have led to the species now being considered endangered (Edsman et al. 2010; Gherardi 2011) with only small and isolated wild populations remaining (Füreder 2009). Limited availability has increased the economic value of this once common consumer good to a luxury food product available in small quantities only on local markets for currently 35-50€/kg live weight (Taugbøl and Skurdal 1988; Franke et al. 2011).

In spite of the danger of the crayfish plague, A. astacus is still of commercial interest due to its high meat content and quality. By excluding the risk of infection and offering stable and controlled growing conditions, recirculating aquaculture systems (RAS) may offer a lower-risk and a more stable and economically viable system for A. astacus production for the food market or for restocking programs, compared to open-pond systems (OPS). Currently, crayfish are cultured in OPS (Ackefors 2000; Cukerzis 1988), where the economic risk of a crayfish plague infection is high and the growth period is limited to a maximum of 6 months per year (Füreder 2009; Taugbøl and Skurdal 1988). In addition, the intensive work load and the mortality rates of up to $90 \%$ due to predation and cannibalism are limiting factors for large farms (Hager 2003; Dethlefs 2007; Daws et al. 2002; Usio et al. 2001). As enclosed systems, RAS may offer secure and adaptable culture conditions for reliable production (Lawson 1995).

However, no specialized RAS adapted to the needs of the A. astacus are available despite other crustacean species, such as the European lobster (Homarus gammarus) and the Australian crayfish (Cherax quadricarinatus), being partly or fully cultured in RAS 
(Manor et al. 2002; Perez Benavente et al. 2010; Knudsen and Tveite 1999; Barki et al. 2006). This is due to culture conditions (related to behavior), restrictions in Europe, workload, and operating and maintenance costs. O. limosus is already cultured in RAS (Auvergne 1979) but is much smaller and barely cannibalistic in contrast to A. astacus (Kozák et al. 2007). The state-of-the-art method for culturing A. astacus and other crayfish species remain OPS (Ackefors 2000; ÓSullivan et al. 2012; Wickins and Lee 2002; Huner 1994), where sufficient space is available to reduce cannibalism, and food is, at a minimum, partially supplied by the pond itself. These systems are exposed to local environmental conditions (i.e., temperature, feed), and production levels are extremely low (Füreder 2009).

Reported feed requirements for freshwater crayfish in general include a lipid content of about $10 \%$, and a protein content of between 25 and $30 \%$ (Valipour et al. 2012; Xu et al. 2013; Jover et al. 1999), and these are also suggested for A. astacus (Ackefors et al. 1992). Although there is no reported specification for A. astacus and no commercial feed available for the species, the basic nutritional requirements outlined above are supplied by various industrial carp feeds.

As A. astacus has not been produced in RAS to date, such a system must be developed in accordance with species needs and given restrictions for animal welfare and food production in the European Union. A further aspect is the cannibalistic behavior at sexual maturity after the 2nd-3rd year. This must be prevented to realize higher stocking densities in comparison with OPS which allow densities of only 1-2 A. astacus per $\mathrm{m}^{2}$. After the development of a suitable RAS, this aspect hast to be investigated to allow a complete production cycle in RAS. Further, the nutrient supply must be analyzed because it is unknown whether nutrient requirements change with crayfish age in natural systems and commercial OPS.

The current study aims to evaluate growth performance and survival of A. astacus in novel RAS and traditional OPS devices in order to determine the general suitability of RAS for culture of the A. astacus. Thus, one-year-old animals will be used excluding cannibalism, which hast to be investigated subsequently. Our specific goals were as follows:

- Document growth rates of $A$. astacus in an RAS, provided with commercial carp feed at three different rations.

- Compare growth of A. astacus between RAS and OPS during the optimal growing period of OPS and at an early age when cannibalism is minimized.

- Compare lipid content of $A$. astacus reared on a commercial diet (RAS) to that of $A$. astacus reared on a natural diet (OPS).

\section{Methods}

Experimental setup and system design

Starting on July 2, 2012, the experiment was carried out in the high summer season, expecting optimal growth rates in OPS, over 60 days until 30th August comparing growth and survival in a RAS (Center for Aquaculture Research, Bremerhaven, Germany) and in an OPS (trout and noble crayfish farm, Poggenhagen, Germany). 
A freshwater RAS rack system was constructed with three stacked levels, each with three 140 -liter tanks per level. The dimensions of one tank were length $0.9 \mathrm{~m}$, width 0.4 , and depth $0.4 \mathrm{~m}$. The water volume of the RAS was approximately $2 \mathrm{~m}^{2}$. The process water drained through pipes at the bottom of the tanks, which were covered with gravel $($ size $=3-6 \mathrm{~cm})$ and halved clay pots as crayfish shelter at a ratio of 1:1. The process water was treated in a separate tank with a fine and a coarse filter (woven filter medium and filter wool) and with an appropriate biofilter volume of 25 liters of bio-medium calculated as follows after (Spieck et al. 2007; van Wyk 1999):

$$
\begin{gathered}
\mathrm{TAN}=\mathrm{Fl}_{\max } \times \mathrm{PC} \times \mathrm{NC} \times \mathrm{NA} \times \mathrm{E}_{\mathrm{NH} 3} \\
V_{\mathrm{BF}}=\mathrm{TAN} / \mathrm{NR} \times \mathrm{A}_{\mathrm{FK}}
\end{gathered}
$$

The water flow for each tank could be adjusted independently to allow a steady inflow of recycled water. The pumps for recirculation and cooling were located in a 140-liter reservoir tank. The water parameters of the dechlorinated tap water were set according to the literature recommendations (Table 2). Light duration (LD) was set to $10 \mathrm{~h}$ per day as an economic interim of OPS LD with $16 \mathrm{~h}$ per day in summer and $8 \mathrm{~h}$ per day in winter. Indoor trials were exposed to neon tubes (OSRAM Daylight, $>6,500 \mathrm{~K}, 5 \mu \mathrm{mol} / \mathrm{m}^{2} \mathrm{~s}^{1}$, OSRAM GmbH, Munich, Germany) from 8 am to $6 \mathrm{pm}$.

\section{OPS}

Commercial requirements limited experimental pond availability to one replicate. The selected pond was centrally positioned within a series-supplied system of seven ponds in total. Flora, microfauna and water parameters were thus stable between OPS within the production system. Historical harvest observations and current season observations indicate no variation from overall pond system performance specifically in terms of crayfish growth and thus highly representative (Göckemeyer, pers. Comm.). Sealed with plastic liner, a foil-lined pond of approximately $100 \mathrm{~m}^{2}$ was selected for the comparative trial with the following dimensions: length $18.1 \mathrm{~m}$, width 5.8 , and depth $1.8 \mathrm{~m}$ with a volume of approximately $190 \mathrm{~m}^{3}$. As in all ponds within the system, waterweed (Elodea spec.) was the dominant aquatic plant in the pond as well as reed (various species) at the corners. Sand, perforated bricks, and perforated sand-lime bricks were distributed as bottom and hiding structures. Besides crayfish, typical lake fauna was present, such as dragonfly larvae, diving beetles, tadpoles, frogs, and aquatic snails. Outdoor trials were exposed to natural daylight $\left[525\right.$ (shady)-835 (sunny) $\left.\mu \mathrm{mol} / \mathrm{m}^{2} \mathrm{~s}^{1}\right]$. LD was on average $15 \mathrm{~h}$ per day with a maximum of 16:45 (2nd July) h and a minimum of 13:45 (30th August) h a day.

Experimental animals and diets

The crayfish used were placed into the OPS 1 year before, in August, as approximately 2-month-old summerlings. An initial collection of 114 A. astacus was carried out at the OPS to supply the RAS device. Ninety crayfish with a mean length of $5.3 \pm 0.8 \mathrm{~cm}$ (mean $\pm \mathrm{SD}$ ) and a mean weight of $4.60 \pm 2.17 \mathrm{~g}$ (mean $\pm \mathrm{SD}$ ) were randomly selected, weighed, and measured at $T_{0}$ and defined as 'Start group' (Table 1). Ten crayfish were assigned to each of the nine trial tanks. Taking the available tank bottom area of $0.35 \mathrm{~m}^{2}$ 
Table 1 Crayfish parameters for each group and tank

\begin{tabular}{|c|c|c|c|c|c|c|c|c|c|}
\hline \multirow[t]{2}{*}{ Tank } & \multicolumn{3}{|c|}{ RAS LOW [3 \%] } & \multicolumn{3}{|c|}{ RAS MED [4 \%] } & \multicolumn{3}{|c|}{ RAS HI [5 \%] } \\
\hline & G 1.1 & G 1.2 & G 1.3 & G 2.1 & G 2.2 & G 2.3 & G 3.1 & G 3.2 & G 3.3 \\
\hline Total weight of group [g] & 45.08 & 47.75 & 45.91 & 43.03 & 45.59 & 48.54 & 44.85 & 46.54 & 46.84 \\
\hline Mean weight of individuals [g] & 4.51 & 4.78 & 4.59 & 4.30 & 4.56 & 4.85 & 4.49 & 4.65 & 4.68 \\
\hline Initial feed ratio $[\mathrm{g}]$ & 1.35 & 1.43 & 1.38 & 1.72 & 1.82 & 1.94 & 2.24 & 2.33 & 2.34 \\
\hline Mean length of individuals $[\mathrm{cm}]$ & 5.3 & 5.3 & 5.2 & 5.3 & 5.2 & 5.3 & 5.3 & 5.2 & 5.2 \\
\hline
\end{tabular}

Initial physical measurements and diet parameters for individual tanks within each RAS ration treatment $G$ group

into account, a stocking density of 28 individuals per $\mathrm{m}^{2}$ was achieved with a biomass of $46.01 \pm 1.55 \mathrm{~g}$ (mean $\pm \mathrm{SD}$ ) per RAS group (Table 1), while in the OPS with approximately 700 animals, the density was at seven per $\mathrm{m}^{2}$. The mean length did not differ among these groups. The weight and length of the approximately 1-year-old crayfish was comparable to expected values as mentioned by Hager (2003) and were supposed to show a measurable growth in the high season and therefore during the experimental period. In order to provide first conclusions about a suitable RAS design, confounding effects of cannibalism, as encountered at later ages, were able to be avoided.

Open-pond system crayfish relied only on natural forage. As an experimental feed for RAS crayfish, the commercial carp feed CYPRININ K2 (Muskator Company, Düsseldorf, Germany) was selected according to the crayfish needs with the following characteristics: grain size $2.0 \mathrm{~mm}$, protein content $25 \%$, fat content $6.8 \%$, fiber content $6.4 \%$, ash content $6.9 \%$, calcium content $1 \%$, and gross energy $14.8 \mathrm{MJ} \mathrm{kg}^{-1}$ (Ackefors et al. 1992). Treatments of $3 \%$ (RAS LOW), $4 \%$ (RAS MED) and $5 \%$ (RAS HI) dry weight/ body weight/day $\left(\mathrm{dw} / \mathrm{bw} / \mathrm{d}^{-1}\right)$ feeding ration were each assigned to three groups of animals. Feeding ratios were selected at $4 \%$ for A. astacus and crayfish in general according to Cukerzies (1988), Masser and Rouse (1997) and Wickins and Lee (2002) and under consideration of the need for economically viable production. The range has been selected to find differences in the upper area of the recommendations. After each measurement, groups were returned to the next tank along the system (i.e., rotated through the tank system) a total of eight times, to even out singular tank influence. Feeding was carried out once daily in the afternoon between 4 and 5 p.m. The pellets were uniformly distributed throughout the tank.

\section{Measurements and sampling}

Adhesive water was taken from the animals before blotted wet weight measurement, and crayfish were placed in a tared glass and weighed with a fine scale CPA2245 (Sartorius, Göttingen, Germany). Total body length was taken by stretching the pleon and measuring from rostrum to telson with an accuracy of $\pm 0.1 \mathrm{~cm}$. Every 2 weeks, all crayfish were weighed, measured and the amounts of feed were adjusted to the new biomass. Oxygen saturation, $\mathrm{pH}$, redox potential, temperature, water hardness and nutrients were measured in both indoor and outdoor trials. As an indication for growth, moltings were recorded in RAS.

At the end of the experiment, all individuals from RAS treatments and 20 individuals from the OPS treatment were sampled, weighed, and measured. The individuals (3\%) 
were fished by blind choice, at different locations and shelters from the whole pond batch of circa 700 animals. From the recorded data, the growth rates were determined and compared for the indoor $(3 \times$ RAS $)$ and outdoor groups $(1 \times$ OPS $)$. After completion of the feeding trial, the specific growth rates (SGR in $\% \mathrm{~d}^{-1}$ ) and increase in biomass (in \%) were determined for each pool as follows:

$$
\mathrm{SGR}=100 \times[\mathrm{LN}(\text { Final Weight })-\mathrm{LN}(\text { Initial Weight }) / \text { Time interval }]
$$

$$
\begin{aligned}
\text { Increase in biomass }[\%]= & {[(\text { Final Weight of Group/Initial Weight of Group })-1] } \\
& \times 100 \%
\end{aligned}
$$

Water parameters

$R A S$

The total hardness and carbonate hardness were measured with a drop test twice weekly (JBL, Neuhofen, Germany). The water parameters were recorded daily from Monday to Friday. The oxygen saturation was measured with a HQ40d meter and an optical sensor LDO101 (HACH LANGE GmbH, Düsseldorf, Germany) and a WTW portable Multi 3,430 $\mathrm{m}$ and an optical sensor 925 FDO-3 (WTW, Weilheim, Germany). To determine the $\mathrm{pH}$, the electrode SenTixU 940-3 (WTW) was used. In the RAS, the values were measured in the three tanks and averaged. The oxygen saturation was measured directly above the tank bottom and the remaining values in the surface water. Tanks were checked twice daily in the morning and evening for dead, diseased, or molted crayfish. For the determination of the dissolved nutrients ammonium $\left(\mathrm{NH}_{4}{ }^{+}\right)$, nitrite $\left(\mathrm{NO}_{2}{ }^{-}\right)$and nitrate $\left(\mathrm{NO}_{3}{ }^{-}\right)$, the compact VIS spectrophotometer DR 2800 (HACH LANGE) was used five times a week from Monday to Friday. Ammonium was measured with Salicylate-method 8155, Nitrite with diazotization-method 8507 and nitrate with the Cadmium reduction-method 8039 (HACH LANGE).

OPS

Water parameters and samples were taken once a week. Each time three water samples were taken from random locations and depths. Oxygen saturation, temperature, $\mathrm{pH}$, and redox potential were measured.

Analytic measurements

Nutrient samples were frozen and transferred to the lab in Bremerhaven for later measurement. For the investigation of dissolved nutrients $\left(\mathrm{NH}_{4}{ }^{+}, \mathrm{NO}_{2}{ }^{-}, \mathrm{NO}_{3}{ }^{-}\right)$, a sample of each bucket $(n=3)$ taken from the pond bottom was filled in a 50-ml Falcon tube and frozen directly at $-20{ }^{\circ} \mathrm{C}$. Light conditions were measured with a Quantum meter over the tank bottom (MQ-200, Apogee Instruments, Utah, USA). To assess the quality of the used feed and available nutrient resources in the OPS, the lipid and energy content of crayfish and feed were analyzed via calorimetry (6100 Compensated Jacket Calorimeter, Parr Instrument Company, Illinois, USA) and lipid extraction after Bligh and Dyer (1959) with the difference that dichloromethane instead of chloroform was used (Christie 1993; Cequier-Sanchez et al. 2008; Li et al. 2014). As a natural food source for A. astacus, the common waterweed Elodea spec. was analyzed to give further conclusions about the 


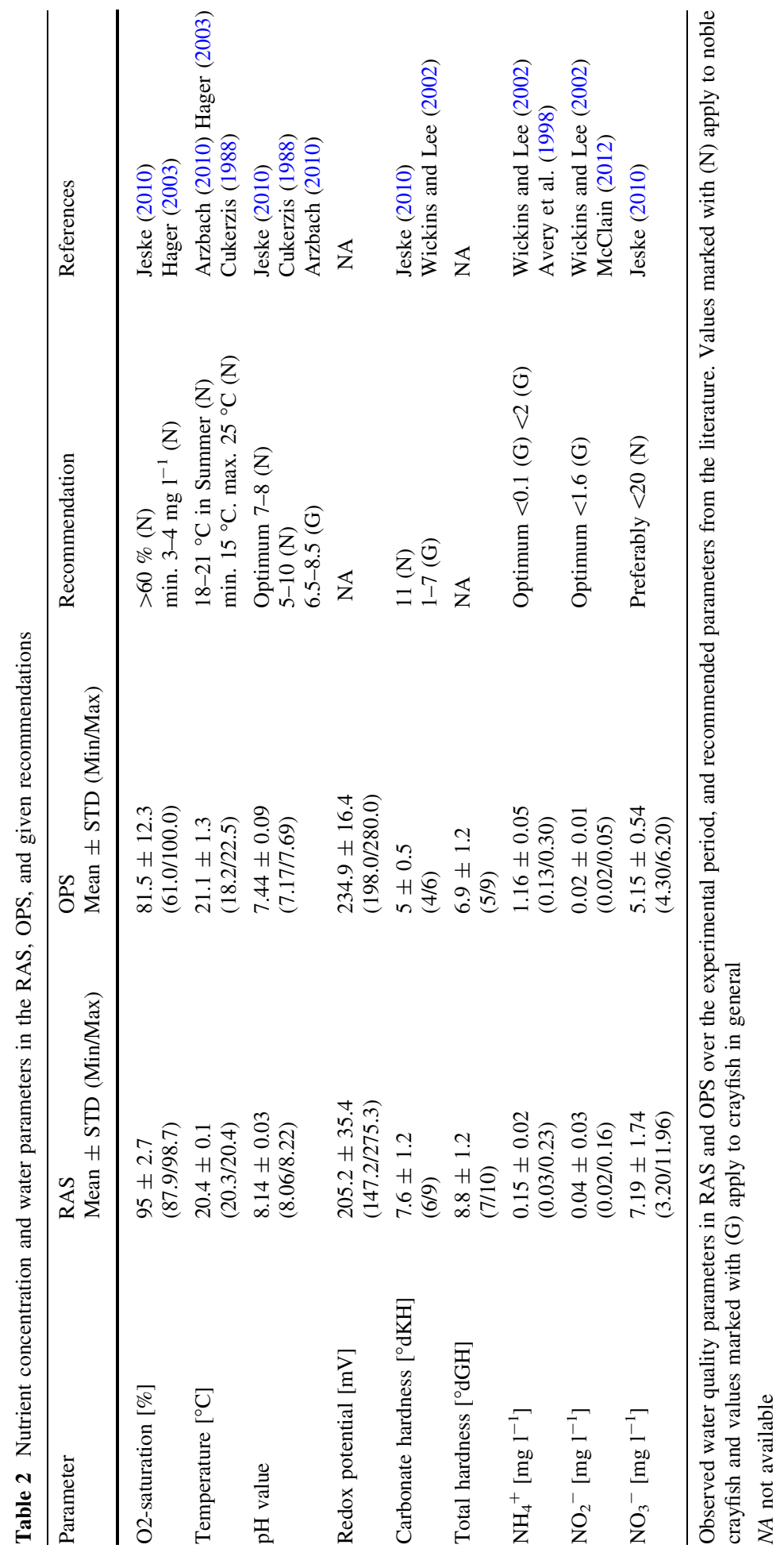


contents needed. Elodea spec. was the only macroalgal species observed in the ponds and was therefore selected as a representative diet. To compare the lipid content in RAS crayfish, crayfish of the OPS were measured and compared with the results of crayfish from RAS and OPS at the end of the experiment. Nine crayfish of each group were sampled.

\section{Statistics}

Statistical analysis was performed using $R$ (Version 2.10.1.) The experimental groups were tested with a Shapiro-Wilk test for normal distribution and with a Bartlett's test for homogeneity of variance. Group comparisons were carried out using $t$ tests or ANOVA as per number of treatments. Tukey post hoc tests were used to determine significant differences in mean values between paired groups. A Kruskal-Wallis test and the Wilcox rank sum-test were performed to determine significant differences between the experimental groups if a normal distribution or homogeneity of variance was not given. Size and weight data and the growth rates were compared by ANOVA to find differences between the RAS treatments. A one sample $t$ test with a confidence interval of $95 \%$ was conducted to compare the RAS treatments to the single OPS as this test makes allowance for the unbalanced experimental design and limited variance calculation capacity for the OPS data. For the comparison of the final length and weight, the mean weight and length of the 20 OPS crayfish were compared to the means of all nine RAS tanks $(n=9)$. For the comparison of the SGR, the SGR for the OPS was calculated of the single mean of the final weight and the single mean of the initial weight. For the RAS crayfish, the SGR was calculated for each replicate tank based on mean initial and final values. The values of the replicate tanks were averaged to calculate the SGR for the given ratios $(n=3)$. Values that were marked by the software $\mathrm{R}$ as outliers were not considered in further calculations. R considers outliers as values located more than 1.5 times of the interquartile range away from the box. This boundary also marks the maximum possible extent of the displayed whiskers.

Assuming that crayfish in RAS could be grown for 12 months under temperature control, annual growth of RAS crayfish was derived from the highest mean treatment SGR rate of the RAS experiment. The growth of OPS crayfish depends on the water temperature which defines the growing season and would last in a worst-case scenario for 4 months and only 6 months in a best-case scenario. Due to missing reference data for annual growth rates, a constant growth rate was assumed across these growth periods (constant growth for 4 months and 6 months, respectively). Growth for OPS crayfish was therefore estimated according to the SGR experiment results, and a best/worst-case scenario with 6 and 4 month growth periods per year was extrapolated.

\section{Results}

Conditions

\section{$R A S$}

Water quality and values were within the tolerance range of the crayfish throughout the experiment (Table 2). Water exchange rate of RAS was at $0.21 \% \mathrm{~d}^{-1}$. The halved clay pots as well as the gravel were well adopted as hiding places by the crayfish during daytime. For regular measuring, the crayfish had to be sought and caught in the gravel which proved to be a time-consuming task. Water hardness $(\mathrm{GH} / \mathrm{KH})$ increased over the 
first month and adjusted around $10^{\circ} \mathrm{dGH}$ and $8^{\circ} \mathrm{dKH}$. The redox potential varied at approx. $205.2 \pm 35.4 \mathrm{mV}$ and the oxygen saturation around $95 \pm 2.7 \%$. The $\mathrm{pH}$ value was stable at $8.14 \pm 0.03$, and the temperature remained constant at $20.4 \pm 0.1{ }^{\circ} \mathrm{C}$. Ammonium concentration varied between 0.10 and $0.21 \mathrm{mg} \mathrm{l}^{-1}$, nitrite concentration was stable at $0.060 \mathrm{mg} \mathrm{l}^{-1}$, and nitrate concentration was between 3.6 and $11.2 \mathrm{mg}^{-1}$. Fifty-five exuviae were found during the experiment indicating a growth phase at the end of the experiment with 40 exuviae found in the last 2 weeks.

\section{OPS}

The temperature varied during the trial period at approx. $21.1 \pm 1.3{ }^{\circ} \mathrm{C}$. The lowest measured value was at $18.2 \pm 0.1{ }^{\circ} \mathrm{C}$, and the highest value at $22.4 \pm 0.1{ }^{\circ} \mathrm{C}$. The oxygen content varied between $64.9 \pm 4.1 \%$ and $98.3 \pm 2.23 \%$. The $\mathrm{pH}$ value was stable at $7.44 \pm 0.09$. The carbonate hardness was constant at $5 \pm 1^{\circ} \mathrm{dKH}$ and total hardness varied between $5^{\circ}$ and $9^{\circ} \mathrm{dGH}$. Ammonium concentration was under $0.2 \mathrm{mg}^{-1}$. Nitrite and Nitrate were constant at $0.022 \pm 0.008$ and $5.1 \pm 0.5 \mathrm{mg}^{-1}$.

\section{Growth performance}

Final length did not differ significantly (ANOVA, $F=0.1, p>0.05$ ) among RAS diet treatments RAS LOW $(5.8 \pm 0.8 \mathrm{~cm})$, RAS MED $(5.9 \pm 0.9 \mathrm{~cm})$, and RAS HI $(5.9 \pm 0.8 \mathrm{~cm})$. However, final length in all RAS treatments was significantly lower (one sample $t$ test, $t=-20.5, p<0.01)$ than that in the OPS treatment $(6.7 \pm 0.8 \mathrm{~cm})$ (Fig. 1). Final weight did not differ significantly (Kruskal-Wallis, df $=2, \chi^{2}=0.44, p>0.05$ ) between RAS diet treatments (RAS LOW: $6.64 \pm 3.41 \mathrm{~g}$; RAS MED: $6.68 \pm 3.68 \mathrm{~g}$; RAS HI: $7.00 \pm 3.24 \mathrm{~g}$ ), but final weight of all RAS treatments was significantly lower

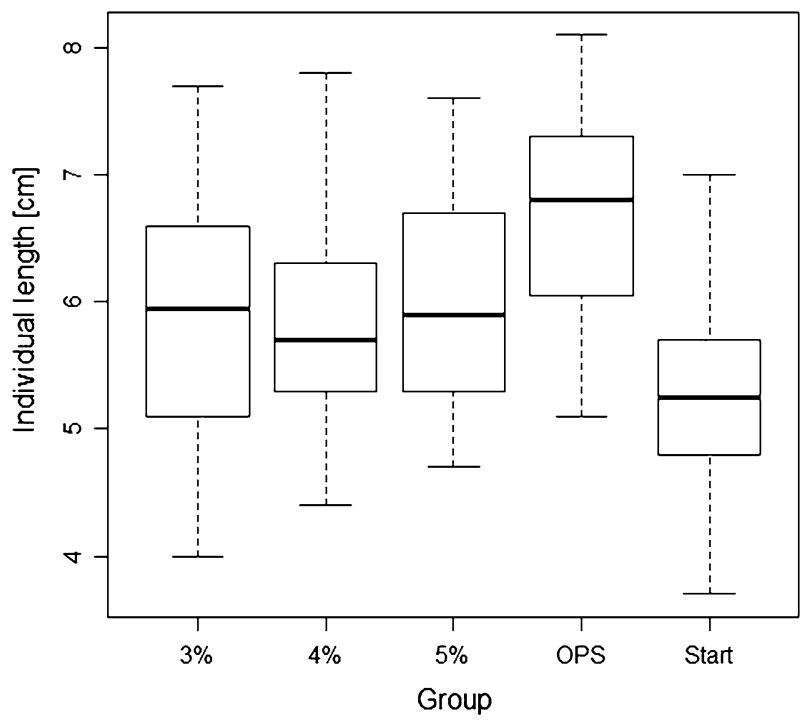

Fig. 1 Boxplot of body length. Initial $(n=90)$ and final $A$. astacus lengths in the RAS LOW (3\%), MED $(4 \%)$, and HI $(5 \%)$ ration treatments $(n=30$ per treatment), and in the OPS treatment $(n=20)$. Whiskers represent one SD. Black lines in each box represent the median value 
(one sample $t$ test, $t=-13.4, p<0.01)$ than that in the OPS treatment $(9.74 \pm 3.85 \mathrm{~g}$ ) (Fig. 2).

Final OPS crayfish biomass (Wilcoxon rank sum-test, $W=197, p<0.01$ ) and length ( $t$ test, $t=-7.3, p<0.01$,) were significantly larger than the initial OPS biomass. RAS crayfish differed from starting OPS group significantly regarding biomass (RAS LOW, RAS MED, RAS HI vs. Start: one sample $t$ test, $t=15.5, p<0.01$ ) and length (RAS LOW, RAS MED, RAS HI vs. Start: one sample $t$ test, $t=13.5, p<0.01$ ).

In total, increase in biomass was $43.4 \pm 8.3 \%$ (RAS LOW), $46.2 \pm 2.4 \%$ (RAS MED), and $52.0 \pm 4.8 \%$ (RAS HI), and OPS crayfish reached $111.7 \%$ (Fig. 3). The highest SGR among RAS crayfish groups was recorded for the RAS HI group $0.78 \pm 0.06 \% \mathrm{~d}^{-1}$ and was still significantly lower (one sample $t$ test, $t=-14.6$, $p<0.01$ ) than OPS crayfish performed with $1.23 \% \mathrm{~d}^{-1}$ (Table 3). Survival was $100 \%$ throughout the experiment in the RAS treatment.

Annualized growth rates calculated as SGR for the RAS HI group $\left(0.78 \pm 0.06 \% \mathrm{~d}^{-1}\right)$ differed significantly from SGR for OPS crayfish assuming a 4-month growth period $\left(0.41 \% \mathrm{~d}^{-1}\right.$; one sample $t$ test, $\left.t=11.5, p<0.01\right)$ and for a 6-month growth period $\left(0.62 \% \mathrm{~d}^{-1}\right.$; one sample $t$ test, $\left.t=4.9, p<0.01\right)$ (Table 4$)$.

\section{Lipid and energy content}

Tissue lipid content did not differ significantly between the RAS groups $5.73 \pm 1.66$ (RAS LOW), $6.93 \pm 1.72 \%$ (RAS MED), and $5.92 \pm 1.54 \%$ (RAS HI), but lipid content of dry weight of OPS crayfish groups was significantly higher than RAS crayfish (KruskalWallis, df $=4, \chi^{2}=18.5, p<0.01$ ). OPS groups had $9.57 \pm 2.21 \%$ (Start) and $8.51 \pm 2.13 \%$ (OPS) (Fig. 4). Due to errors in analytical measurements, the replicate numbers of group RAS HI and OPS were lowered to $n=5$ and $n=8$.

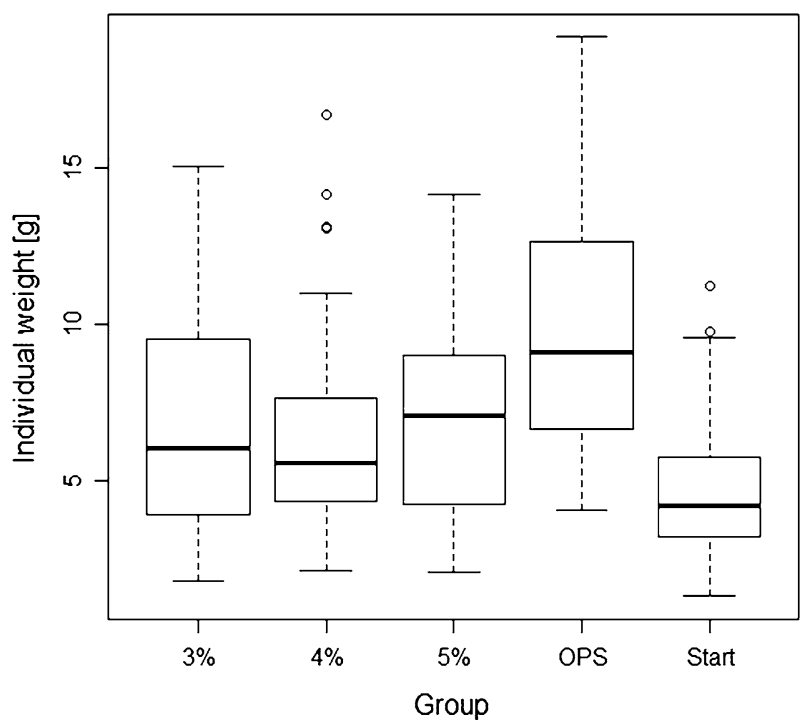

Fig. 2 Boxplot for body weight. Initial $(n=90)$ and final A. astacus weights in the RAS LOW (3\%), MED (4\%), and HI $(5 \%)$ ration treatments $(n=30$ per treatment), and in the OPS treatment $(n=20)$. Whiskers represent one SD. Black lines in each box represent the median value. Circles represent outlier values that were omitted from statistical analysis 


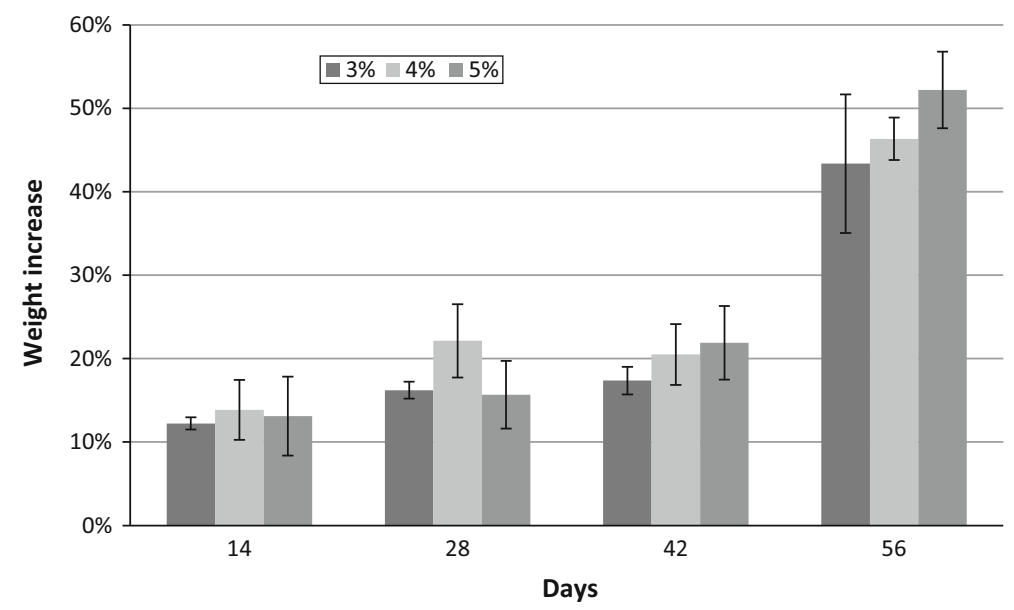

Fig. 3 Growth performance showing the growth increase of RAS groups. Mean cumulative increase in biomass $(\mathrm{g}) \pm \mathrm{SD}$ of $A$. astacus per tank by treatment $(n=3)$ over the experimental period

Table 3 Annual growth rates of A. astacus in RAS and OPS

\begin{tabular}{lllllll}
\hline System & RAS HI & RAS MED & RAS LOW & OPS & OPS-4 & OPS-6 \\
\hline SGR $\left[\%\left(\mathrm{~d}^{-1}\right)\right]$ & 0.78 & 0.71 & 0.67 & 1.24 & 0.41 & 0.62 \\
\hline
\end{tabular}

RAS and OPS assume a 12-month growing period, while OPS-4 and OPS-6 assume a 4- and 6-month growing period, respectively

Table 4 Energy content of feed and waterweed

\begin{tabular}{lll}
\hline Sample & $\begin{array}{l}\text { Energy } \\
\text { Mean } \pm \mathrm{SD}\left[\mathrm{MJ} \mathrm{kg}^{-1} \mathrm{dm}\right]\end{array}$ & $\begin{array}{l}\text { Lipid } \\
{[\%]}\end{array}$ \\
\hline Cyprinin K2 & $16.95 \pm 0.11$ & $4.1 / 4.6$ \\
Elodea spec. & $14.70 \pm 0.10$ & 8.5 \\
\hline
\end{tabular}

Energy and lipid content of feed and waterweed samples of dry matter $(n=3)$

Change in tissue lipid content over the experimental period was $-2.78 \pm 1.66 \%$ (RAS LOW), $-1.58 \pm 1.72 \%$ (RAS MED), $-2.59 \pm 1.54 \%$ (RAS HI), and $+1.06 \% \pm 2.21$ in OPS crayfish. Lipid content of the feed ranged from 4.1 to $4.5 \%$. Mean energy content of the feed CYPRININ K2 was $16.95 \pm 0.11 \mathrm{MJ} \mathrm{kg}^{-1} \mathrm{dw}$ (higher than stated by the manufacturer $-14.8 \mathrm{MJ} \mathrm{kg}^{-1}$ ) (Table 4). Lipid content of Elodea spec. was $8.5 \%$ and the mean energy content $14.70 \pm 0.10 \mathrm{MJ} \mathrm{kg}^{-1} \mathrm{dw}$ (Table 4).

\section{Discussion}

Recirculating aquaculture systems holding of the commercially valuable noble crayfish $A$. astacus may offer advantages over traditional OPS holding in terms of exclusion of disease and other external influences. In the current study, 16-month-old A. astacus held in RAS 


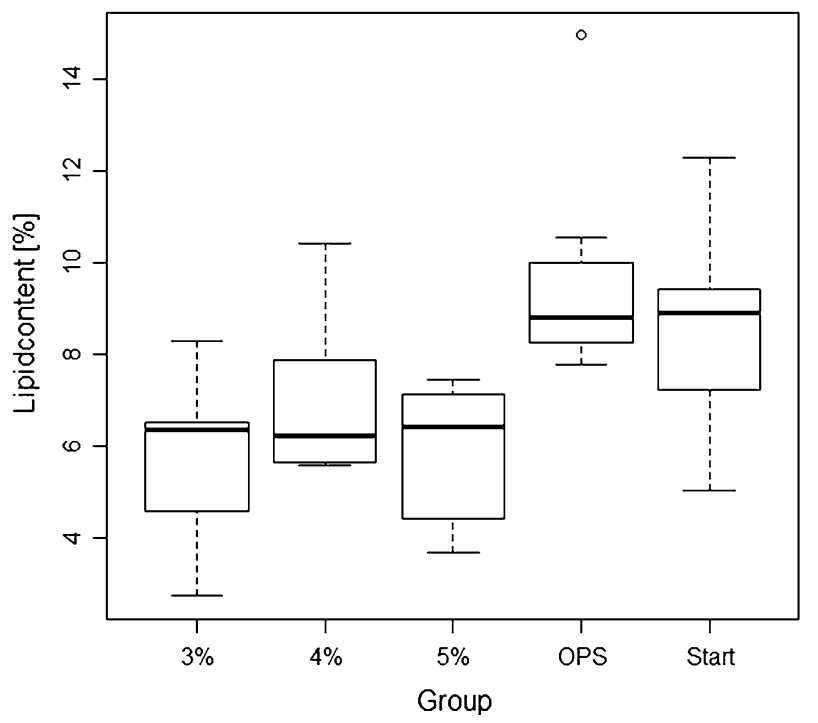

Fig. 4 Lipid content per group. Tissue lipid content of A. astacus [\%] of dry matter by treatment RAS LOW (3\%), MED (4\%) and Start with $n=9$, RAS HI (5\%) with $n=5$, and OPS with $n=8$. Whiskers indicate one standard deviation. Black line in each box represents the median value

exhibited excellent survival and growth rates which, while lower than in the OPS treatment over the experimental period, are higher than that reported by Franke et al. (2011) using comparable conditions (14-15 month-old crayfish, stocking densities of $15-60$ per $\mathrm{m}^{2}, \mathrm{LD}$ 16:8) using a diet with higher protein levels.

Specific growth rates of OPS crayfish in the current study were significantly higher than in RAS despite less optimal water conditions regarding temperature and oxygen saturation. The mean crayfish length measured in OPS in the current study corresponds to 18-monthold crayfish, thus growth in OPS in the current study also exceeded reported mean growth in OPS from previous studies (Hager 2003). These findings may be explained by the chosen experimental period. July and August offer the best growth conditions, e.g., water temperature and nutrient support, for OPS crayfish, and therefore, the annualized SGR values calculated herein are not representative of the whole period of growth from May to October let alone the full calendar year. Annualized growth of crayfish in RAS under the circumstances investigated, taking into account the winter growth cessation in OPS, clearly indicate that RAS can already outperform OPS regarding growth over periods exceeding the current study duration. RAS holding resulted in improved survival, biosecurity, controllability, and lower work input. Whether these benefits would facilitate an economically viable production system remains to be answered. Nevertheless, there is potential for optimizing growth rates compared to OPS, further enhancing the efficiency and profitability of such a system.

One potential explanation for the higher growth performance in OPS in the current study is the lower overall holding density in unfed OPS (7 animals $\left.\mathrm{m}^{2}\right)$ as compared to RAS (28 animals $\mathrm{m}^{2}$ ), which may have provided crayfish with a much larger overall food supply per animal irrespective of diet value. Alternatively, as also indicated by the higher lipid content in OPS crayfish tissues, there may be a better nutrient supply in the available natural diet in OPS in the pond treatment, which gave animals the opportunity to grow 
faster and build up fat reserves. If correct, this indicates the need for artificial diet optimization in RAS treatments to obtain optimal growth rates in A. astacus. The protein concentration of the carp feed used appears to be too low to support optimal growth. This assumption is supported by the SGR of the RAS groups which did not vary significantly despite variation in feed rations, while the feed itself was not fully consumed even at the lowest ration. In addition, higher SGR with a lower feed ratio of 1-2\% but with higher protein contents between 40 and $60 \%$ were reported by research colleagues (Pasini, pers. Comm.). Secondly, the tissue fat content of OPS crayfish was higher which indicates that OPS crayfish had the possibility to build up fat reserves due to a more suitable overall nutrient supply.

Protein contents for various crayfish diets (e.g., A. astacus, A. leptodacthylus, Procambarus clarkii) are stated between 25 and $30 \%$ (Ackefors et al. 1992; Valipour et al. 2012; Xu et al. 2013; Ghiasvand et al. 2012). Considering the current results and the protein content $(25 \%)$ of the diet used, different feed ratios per group and the better SGR in the OPS, it might be necessary to reconsider the proposed protein content of crayfish feed in general and with respect to the crayfish age (Ackefors et al. 1992).

Lipid content in the feed was, in accordance to the majority other crayfish studies, low (Xu et al. 2013; Carmona-Osalde et al. 2005; Ghiasvand et al. 2012) and should be enhanced with the crayfish age (Ackefors et al. 1992). Although higher lipid levels were stated (Valipour et al. 2012), the feed and its lipid content was chosen in accordance to the natural nutrient for A. astacus supply stated by Hager (2003). Energy content of the feed was in the range of other studies and given recommendations as mentioned before as well as in the range of the representative Elodea spec. as a natural food source. Growth and tissue lipid results indicate that crayfish in OPS used a wider food spectrum than assumed with lower concentrations of vegetable fiber. Resources with higher protein contents like insects may play a more important role in the food spectrum of A. astacus than previously assumed. In future, fatty acid profiling of OPS specimens may provide insights into diet range.

The three selected feed ratios and groups did not differ significantly regarding the growth increase of the crayfish, indicating that a higher ratio would not have increased growth. In addition, the feed was not completely consumed. Rather than a too low feed ratio, this indicates that the feed did not match the crayfish needs. Alongside nutrient content, another reason for the moderate growth performance in RAS could be due to the shape of the feed. The sticks proved to be very handy but lost their shape quite fast and with it the most important factor for crayfish feeding (Wittmaak 2006; Hager 2003). As indicated by Wittmaak (2006), crayfish prefer a handlable feed more than a high nutrient content with an unhandlable structure which could have led to poorer feeding performance and thus slower growth in RAS than in OPS.

With a $100 \%$ survival rate, RAS proved its value for culturing 1-year-old A. astacus regarding environmental settings and reliability. Survival rates in a yearly cleaned OPS are approximately at $79.7 \%$ for 1-year-old A. astacus stocked at densities of eight crayfish per $\mathrm{m}^{2}$. Three ponds of $110 \mathrm{~m}^{2}$ each were stocked with 2.100 crayfish in total and monitored. Ponds were emptied each year and crayfish were counted (Seemann, unpub. data). All water parameters in the RAS were able to be held in accordance to the crayfish needs and the requirements of RAS (EIFAC 1998) and were held constantly on this level during the experiment (Hager 2003; Jeske 2010; Sander 1998; Wickins and Lee 2002; Füreder 2009). Therefore, crayfish mortality and growth should not have been affected by these conditions. The molting interval represented normal growth for A. astacus in summer (Hager 2003). 
The parameters in the OPS were also within the tolerance range but varied much more than the RAS parameters (Arzbach 2010; Hager 2003). The dissolved nutrients in the RAS as well as in the OPS were in a comparable range and fulfilled the given recommendations (Jeske 2010; McClain 2012; Wickins and Lee 2002).

Other limiting parameters like a higher stress level while measuring the crayfish and maintaining the RAS as well as the OPS could have had an influence on the growth but would have a similar effect, even when the OPS was visited less frequent on a daily routine and when samples were taken from the trial pond each week.

\section{Conclusion}

While the current results show higher growth rates in OPS crayfish, particularly during the high season, overall annual growth in RAS may be higher, particularly if diets are optimized. Furthermore, high recorded survival rates in RAS are advantageous for culturing one-year-old A. astacus at extremely high stocking density and promising for crayfish culture overall if these survival rates can be maintained in older animals.

The most important factor influencing growth in this experiment was the carp feed used which resulted in a $100 \%$ survival and acceptable growth rates, but did not fully replace the natural nutrient supply of the crayfish nor the natural handling of these resources. Therefore, an optimized feed with higher protein content and water stability should be tested. Whether the benefits of better annualized growth, higher survival rates, security, controllability, and work input along with a new feed composition potentially including diet additives to improve growth rates can result in an economically viable production system has to be further investigated.

Acknowledgments We would like to thank the reviewers for their time and thorough reviews which we believe have significantly improved the manuscript. The study was supported by Grants from the Deutsche Bundesstiftung Umwelt Germany (AZ 28879).

\section{References}

Ackefors HEG (2000) Freshwater crayfish farming technology in the 1990s: a European and global perspective. Fish Fish 1:337-359

Ackefors H, Castell JD, Boston LD, Räty P, Svensson M (1992) Standard experimental diets for crustacean nutrition research. II. Growth and survival of juvenile crayfish Astacus astacus (Linné) fed diets containing various amounts of protein, carbohydrate and lipid. Aquaculture 104:341-356

Arzbach H-H (2010) Biologie. Ökologie und Verhalten der Flusskrebse, Krebsseminar Echem, Echem

Auvergne A (1979) Culture of crayfish. In: L'élevage des écrevisses. Maisons-Alfort, La Zoothèque du Point Vétérinaire, p 87

Avery JL, Romaire RP, McClain, WR (1998) Crawfish production production economics, pond construction and water supply. South Reg Aquac Cent 240:1-4

Barki A, Karplus I, Manor R, Parnes S, Aflalo ED, Sagi A (2006) Growth of redclaw crayfish (Cherax quadricarinatus) in a three-dimensional compartments system: does a neighbor matter? Aquaculture 252:348-355

Bligh EG, Dyer WJ (1959) A rapid method of total lipid extraction and purification. Can J Biochem Physiol 37:911-917

Carmona-Osalde C, Olvera-Novoa MA, Rodriguez-Serna M (2005) Effect of the protein-lipids ratio on growth and maturation of the crayfish Procambarus (Austrocambarus) llamasi. Aquaculture 250:692-699

Cequier-Sanchez E, Rodriguez C, Ravelo AG, Zarate R (2008) Dichloromethane as a solvent for lipid extraction and assessment of lipid classes and fatty acids from samples of different natures. J Agric Food Chem 56:4297-4303 
Christie WW (ed) (1993) Preparation of lipid extracts from tissues. In: Advances in lipid methodology. Oily Press, Dundee, pp 195-213

Cukerzis JM (1988) Astacus astacus in Europe. In: Holdich DM, Lowery RS (eds) Freshwater crayfish: biology, management and exploitation. Croom Helm, London, pp 309-340

Daws AG, Grills J, Konzen K, Moore PA (2002) Previous experiences alter the outcome of aggressive interactions between males in the crayfish, Procambarus Clarkii. Mar Freshw Behav Physiol 35:139-148

Dethlefs A (2007) Predator-Pray-Interaction between Dragonfly Larva (Odonata: Anisoptera) and Crayfish Juveniles (Astacus astacus). In: Zoological Institute-Department Limnology. Christian-Albrechts, University Kiel, Kiel, Germany, p 124

Edgerton BF, Evans LH, Stephens FJ, Overstreet RM (2002) Synopsis of freshwater crayfish diseases and commensal organisms. Aquaculture 206:57-135

Edsman L, Füreder L, Gherardi F, Souty-Grosset C (2010) Astacus astacus-Status report. In: The IUCN Red List of Threatened Species. International Union for Conservation of Nature and Natural Resources

EIFAC (1998) Report of the Symposium on Water for Sustainable Inland Fisheries and Aquaculture held in connection with the European Inland Fisheries Advisory Commission. In: Food and Agriculture Organization of the United Nations. FAO, Rome, p 56

Franke R, Wessels S, Horstgen-Schwark G (2011) Enhancement of survival and growth in crowded groups: the road towards an intensive production of the noble crayfish Astacus astacus L. in indoor recirculation systems. Aquac Res 44:451-461

Füreder L (2009) Flusskrebse Biologie-Ökologie-Gefährdung. Naturmuseum Südtirol, Wien

Gherardi F (2011) Towards a sustainable human use of freshwater crayfish (Crustacea, Decapoda, Astacidea). Knowl Manag Aquat Ecosyst 401:1-2. doi:10.1051/kmae/2011038

Ghiasvand Z, Matinfar A, Valipour A, Soltani M, Kamali A (2012) Evaluation of different dietary protein and energy levels on growth performance and body composition of narrow clawed crayfish (Astacus leptodactylus). Iran J Fish Sci 11:63-77

Hager J (2003) Edelkrebse-Biologie, Zucht, Bewirtschaftung. Leopold Stocker Verlag, Graz

Holdich DM (2002) Distribution of crayfish in Europe and some adjoining countries. Bull Fr Pêche Piscic 367:611-650

Holdich DM, Reynolds JD, Souty-Grosset C, Sibley PJ (2009) A review of the ever increasing threat to European crayfish from non-indigenous crayfish species. Knowl Manag Aquat Ecosyst 394-395:11

Huner JV (1994) Freshwater Crayfish Aquaculture in North America, Europe, and Australia: Families Astacidae, Cambaridae, and Parastacidae. CRC Press, Boca Raton

Ingle R (1997) Crayfishes, lobsters and crabs of Europe: an illustrated guide to common and traded species. Springer, Berlin

Jeske H (2010) Edelkebs Astacus astacus-Zucht. Vermehrung und Bewirtschaftung von Edelkrebsen, Krebsseminar, Echem

Jover M, Fernandez-Carmona J, Del Rio M, Soler M (1999) Effect of feeding cooked-extruded diets, containing different levels of protein, lipid and carbohydrate on growth of red swamp crayfish (Procambarus clarkii). Aquaculture 178:127-137

Knudsen H, Tveite S (1999) Survival and growth of juvenile lobster Homarus gammarus L. raised for stock enhancement within in situ cages. Aquac Res 30:421-425

Kozák P, Buřič M, Policar T, Hamáčková J, Lepičová A (2007) The effect of inter- and intra-specific competition on survival and growth rate of native juvenile noble crayfish Astacus astacus and alien spiny-cheek crayfish Orconectes limosus. Hydrobiologia 590:85-94

Lawson T (1995) Recirculating aquaculture systems. Fundamentals of aquacultural engineering. Springer, US, pp 192-247

Li Y, Naghdi FG, Garg S, Adarme-Vega TC, Thurecht KJ, Ghafor WA, Tannock S, Schenk PM (2014) A comparative study: the impact of different lipid extraction methods on current microalgal lipid research. Microb Cell Fact 13:14

Manor R, Segev R, Leibovitz MP, Aflalo ED, Sagi A (2002) Intensification of redclaw crayfish Cherax quadricarinatus culture: II. Growout in a separate cell system. Aquacult Eng 26:263-276

Masser MP, Rouse DB (1997) Australian red claw crayfish. South Reg Aquac Cent 244:1-8

McClain WR (2012) Crawfish production: pond construction and water requirements. South Reg Aquac Cent 240:6

ÓSullivan DD, Jones C, Fielder D (2012) Freshwater crustaceans. In: Lucas JSS, Paul C (eds) Aquaculture: farming aquatic animals and plants. Wiley, NY, p 948

Perez Benavente G, Uglem I, Browne R, Marino Balsa C (2010) Culture of juvenile European lobster (Homarus gammarus L.) in submerged cages. Aquacult Int 18:1177-1189

Sander M (1998) Aquarientechnik im Süß- und Seewasser. Ulmer, Stuttgart 
Skurdal J, Taugbøl T (2001) Crayfish of commercial importance. In: Holdich DM (ed) Biology of freshwater Crayfish. Blackwell Science, Oxford, pp 467-510

Spieck E, Josza P-G, Alawi M, Brill F, Quantz G, Beth S, Wolbeck R, Watermann B (2007) Entwicklung neuartiger Trägermaterialien für die Wasseraufbereitung und Kreislaufführung in Marikultur-Produktionsanlagen der Fischzucht. DBU, Osnabrück

Taugbøl T, Skurdal J (1988) Increased proportion of mature females of the noble crayfish (Astacus astacus L.) in culture conditions. Aquaculture 69:39-42

Usio N, Konishi M, Nakano S (2001) Species displacement between an introduced and a 'vulnerable' Crayfish: the role of aggressive interactions and shelter competition. Biol Invasions 3:179-185

Valipour A, Ozorio ROA, Shariatmadari F, Abedian A, Seyfabadi J, Zahmatkesh A (2012) Effects of dietary lipid levels on growth, survival, and molting of yearling narrow clawed crayfish, Astacus leptodactylus. J Appl Aquac 24:316-325

van Wyk P (1999) Principles of Recirculating System Design. In: Van Wyk P, Davis-Hodgkins M, Laramore R, Main KL, Mountain J, Scarpa J (eds) Farming marine shrimp in recirculating freshwater systems. Department of Agriculture and Consumer Services, Florida, p 90

Westman K (2002) Alien Crayfish in Europe: negative and positive impacts and interactions with native Crayfish. In: Leppäkoski E, Gollasch S, Olenin S (eds) Invasive aquatic species of Europe distribution, impacts and management. Springer, Netherlands, pp 76-95

Westman K, Savolainen R (2001) Long term study of competition between two co-occurring Crayfish species, the native Astacus astacus L. and the introduced Pacifastacus leniusculus Dana, in a Finnish lake. Bull Fr Pêche Piscic 361:613-627

Wickins JFL and Lee DO'C (2002) Crustacean farming: ranching and culture. Wiley-Blackwell, NY

Wittmaak KE (2006) Ernährungsökologische Untersuchungen an Krebsen. Christian Albrechts Universität zu Kiel, Kiel

Xu WN, Liu WB, Shen MF, Li GF, Wang Y, Zhang WW (2013) Effect of different dietary protein and lipid levels on growth performance, body composition of juvenile red swamp crayfish (Procambarus clarkii). Aquacult Int 21:687-697 